\title{
УдК 621.382
}

\section{$3852.2+\Gamma 125.375 \cdot 25$}

'С.В. Лєнков, д-р техн. наук

${ }^{2}$ Д.В. Лукомський

${ }^{3}$ В.А. Мокрицький, д-р техн. наук

${ }^{4}$ В.А. Завадський, канд. техн. наук

${ }^{5}$ Р.М.Салімов, канд. техн. наук

\section{РАДІАЦЙНО-ТЕРМГЧНЕ КОРЕГУВАННЯ ВЛАСТИВОСТЕЙ АРСЕНЦДУ ГАЛІЮ}

${ }^{1,5}$ Національний авіаційний університет, ipn@nau.edu.ua

${ }^{2}$ Одеський національний політехнічний університет

${ }^{3}$ ВАТ "Квазар"

${ }^{4} О$ деська національна морська академія

Розглянуто результати досліджень можливостей корегування параметрів і характеристик електронних приладів на основі арсениду галію, цо використовусться в радіоелектронних елементах бортової апаратури. Наведено експерииентальні дані иодо керування властивостями підкладок $i$ епітаксійних шарів арсеніду галію через опромінення нейтронами $i$ наступний відпал.

У бортовій радіоелектронній апаратурі широко використовують елементи, шо побудовані на монокристалічному i епітаксійному арсеніді галію. Ці елементи є найвідповідальнішими в системах бортової радіолокації зв'язку, керування роботою бортових приладів, навігації, наведення тощо. Деякі 3 них функціонують в умовно відкритому просторі i піддаються різноманітним радіаційним випромінюванням та впливам високоенергетичних частинок, зокрема швидких нейтронів. Крім того, на них впливають значні перепади температур. Радіаційний та температурний вплив може бути як небажаним, так і корисним.

У наукових роботах $[1 ; 2]$ висвітлено результати досліджень радіаційного впливу на параметри підкладок та шарів арсеніду галію, однак не повною мірою вивчені особливості нейтронного опромінення та наступного відпалу.

У роботі [3] наведено результати досліджень керування процесами рідинно-фазної епітаксії та дифузії домішок за допомогою швидких електронів і нейтронів, протонів та гамма-квантів. Розглянемо стійкість об'ємних монокристалів і епітаксійних шарів германія, кремнія, природних елементів та алмазоподібних плівок до дії іонізуючих випромінювань. У роботі [4] наведено результати досліджень впливу опромінення швидкими електронами на властивості арсеніду галію.

Запропонована стаття $є$ органічним продовженням робіт [3-6]. Вона присвячена дослідженню можливостей корегування параметрів підкладок і епітаксійних шарів арсеніду галію за рахунок опромінення нейтронами i наступного відпалу.
Порівняння 3 результатами опромінення електронами показує, пцо стійкість шарів до опромінення нейтронами залежить значною мірою від дози опромінення. Опромінення дозами нейтронів більше ніж $5 \cdot 10^{15} \mathrm{~cm}^{-2}$ викликає значні зміни електрофізичних властивостей шарів [5]. Оцінимо в цих умовах темп компенсації носіїв заряду радіаційними дефектами. Вважаємо, що процес виведення носіїв заряду протікає за експонентним законом [6]:

$$
n=n_{0} \exp \left(-K_{\mathrm{n}} \Phi_{\mathrm{n}}\right),
$$

де $n_{0}, n-$ концентрація носіїв заряду відповідно до і після опромінення; $K_{\mathrm{n}}-$ коефіцієнт, що характеризує швидкість виведення носіїв заряду; $\Phi_{\mathrm{n}}$ - доза опромінення нейтронами.

При опроміненні дозами нейтронів $(1 \div 100) \times$ $\times 10^{14} \mathrm{~cm}^{-2}$ і початкової концентрації вільних носіїв заряду в межах $(2 \div 200) \cdot 10^{16} \mathrm{~cm}^{-3}$ виявицося, шо коефіцієнт $K_{\mathrm{n}}$ залежить не тільки від початкової концентрації носіїв у епітаксійному шарі, але й від дози опромінення (рис. 1). Така залежність мас складний характер. Це дозволяє припустити існування, принаймні, двох різних за своєю природою механізмів впливу нейтронного опромінення на властивості епітаксійних шарів арсеніду галію.

Термічному відпалу піддавалися шари арсеніду галію $з$ різним ступенем легування і типом легуючої домішки, які опромінені різними дозами нейтронів. Відпал виконували в захисній атмосфері протягом 20 хв при температурі від +100 до $+600^{\circ} \mathrm{C}$ з вимірюванням параметрів шарів через кожні $50^{\circ} \mathrm{C}$.

За результатами відпалу всі зразки можна умовно розбити на три групи. 


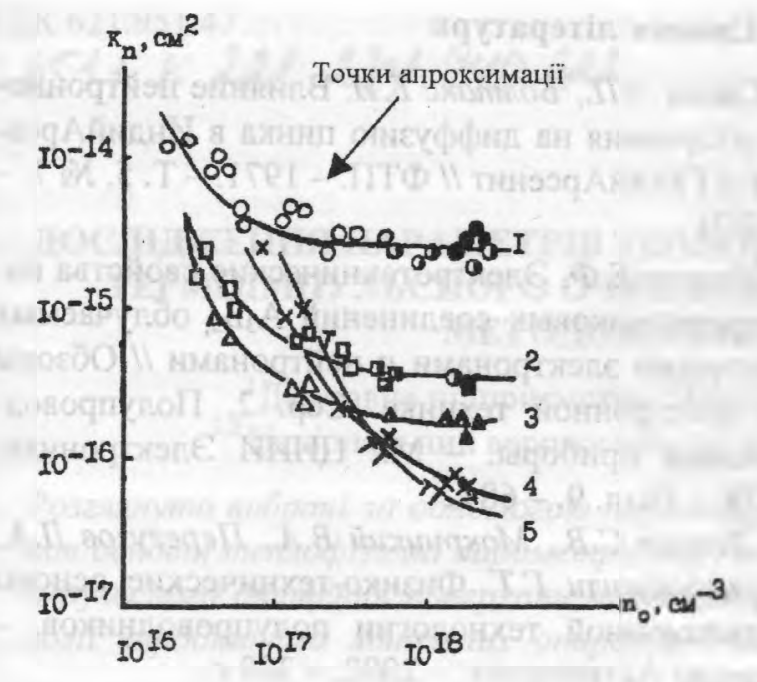

Рис. 1. Залежність швидкості виведення носї̈в заряду в епітаксійних шарах арсеніду галію від початкової концентрації носіїв у шарі, опроміненому нейтронами:

$1-1 \cdot 10^{14} \mathrm{~cm}^{-2} ; 2-5 \cdot 10^{14} \mathrm{cM}^{-2} ; 3-1 \cdot 10^{15} \mathrm{~cm}^{-2}$;

$4-5 \cdot 10^{15} \mathrm{CM}^{-2} ; 5-1 \cdot 10^{16} \mathrm{~cm}^{-2}$

До першої групи відносять зразки, відновлення параметрів яких відбувається стрибкоподібно при температурі $+(200 \div 300)^{\circ} \mathrm{C}$ (рис. 2) і подальший відпал не впливає на властивості шарів. Термін відпалу -20 хв.

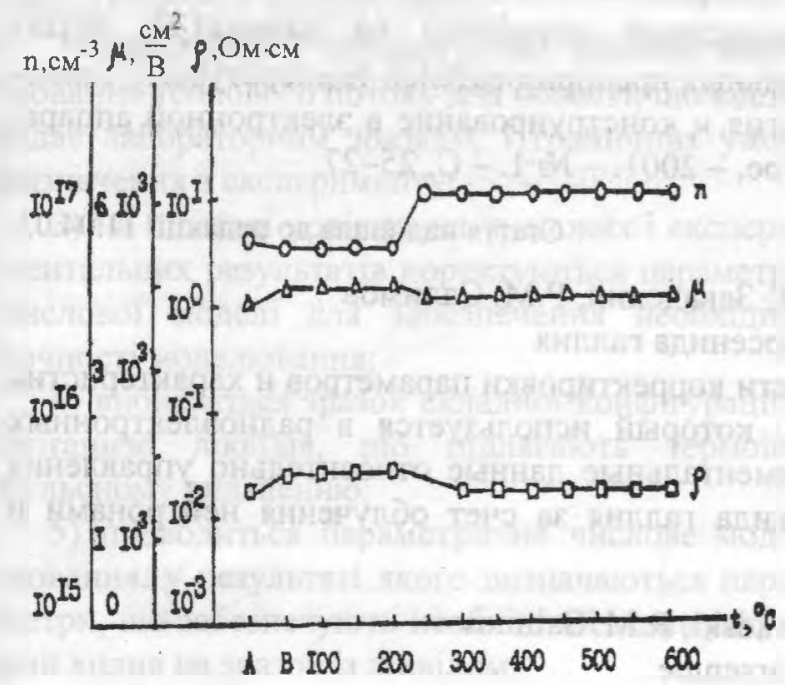

Рис. 2. Залежність питомого опору $\rho$, концентрації носіїв заряду $n$ і їхньої рухливості $\mu$ від температури відпалу для зразків першої групи: $A$ - параметр шару до опромінення нейтронами; $B$ - параметр шару після опромінення нейтронами

У другій групі процес відпалу відбувається в два етапи. Термін відпалу - 20 хв. Спочатку при температурі $+200 \div+300^{\circ} \mathrm{C}$ спостерігалося невелике поліпшення характеристик. Наприклад, для дуже компенсованих радіаційними дефектами шарів тепер можливе раніше недоступне вимірювання параметрів, для менш компенсованих - зменшується ступінь компенсації радіаційними дефектами, зростає рухливість і зменшується опір шару (рис. 3). При підвищенні температури відпалу електрофізичні характеристики поступово поліпшувалися, i при $\mathrm{t}=+550 \div+600^{\circ} \mathrm{C}$ отримано повне відновлення вихідних властивостей.

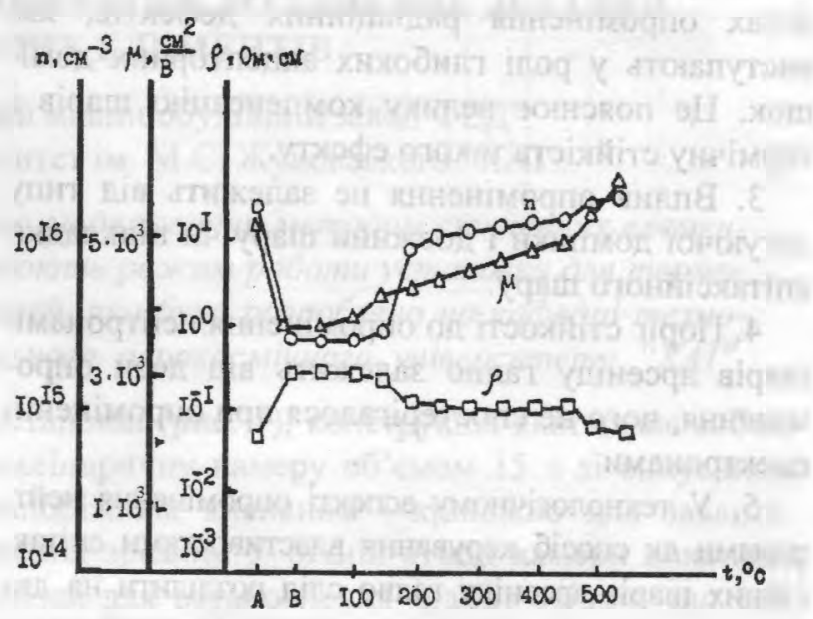

Рис. 3. Залежність питомого опору $\rho$, концентрації $n$ і рухливості носіїв заряду $\mu$ від температури відпалу для зразків другої групи 3 незначним погіршенням властивостей після опромінення нейтронами:

$A$ - параметр шару до опромінення нейтронами;

$B$ - параметр шару після опромінення нейтронами

До третьої групи відносять зразки зі значним ступенем компенсації радіаційними дефектами $\left(\ln \frac{n}{n_{0}} ; \frac{\mu}{\mu_{0}} \triangleleft \triangleleft 1\right)$. Параметри таких шарів після опромінення за рахунок великої компенсації вимірити методом Ван-дер-Пау не вдається. У цьому випадку відпал радіаційних дефектів починасться тільки при $t=+500^{\circ} \mathrm{C}$, і при $\mathrm{t}=+550^{\circ} \mathrm{C}$ властивості таких шарів цілком відновлювалися.

\section{Висновки}

Вплив опромінення нейтронами на електрофізичні параметри епітаксійних шарів арсеніду галію призводить до таких результатів.

1. Вплив нейтронів на електрофізичні параметри епітаксійних шарів арсеніду галію характеризується існуванням деякого порога в значення дози опромінення. До опромінення нейтрони не впливають чи поліпшують властивості шарів, а після опромінення іх параметри погіршуються стрібкоподібно. За цією ознакою таку дозу можна умовно вважати порогом стійкості властивостей шарів до опромінення нейтронами.

2. Перший випадок може бути викликаний переходом під дією нейтронів власних атомів кристалічних грат шару 3 міжвузельного в регулярне положення. Поліпшення структури 
при цьому змінює умови розсіювання і генерації носіїв заряду. Крім того, в цьому випадку велика ймовірність утворення кластерів типу "радіаційний дефект - домішка - вакансія", які сприяють стоку вільних носіїв заряду. Другий випадок може бути обумовлений створенням при великих дозах опромінення радіаційних дефектів, які виступають у ролі глибоких акцепторних домішок. Це пояснює велику компенсацію шарів і термічну стійкість такого ефекту.

3. Вплив опромінення не залежить від типу легуючої домішки і довжини шару чи підкладки епітаксійного шару.

4. Поріг стійкості до опромінення нейтронами шарів арсеніду галію залежить від дози опромінення, чого не спостерігалося при опроміненні електронами.

5. У технологічному аспекті опромінення нейтронами як спосіб керування властивостями епітаксійних шарів арсеніду галію слід розділити на два види залежно від дози опромінення. Перший вид малі дози опромінення до $1 \cdot 10^{15} \mathrm{~cm}^{-2}$. Він може служити засобом поліпшення властивостей шарів і $є$ найбілыи ефективним для шарів із початковою конццентрацією вільнгі носіїв заряду більш ніж $1 \cdot 10^{17} \mathrm{~cm}^{3}$. Другий вид - дози опромінення більш ніж $5 \cdot 10^{15} \mathrm{~cm}^{-3}$. Основний ефект цього впииву погіршення властивостей шарів арсеніду галію. Дпя підвищення стійкості до даного виду опромінення необхілно легувати шари до концентрації легуючої домішки не менш ніж $5 \cdot 10^{18} \mathrm{~cm}^{-3}$.

\section{Список літератури}

1. Савин Э.П., Болтакс Г.И. В.тияние нейтронного облучения на диффузию цинка в ИндийАрсенит и ГалийАрсенит // ФТП. - 1971. - Т. 5, № 7. C13/31.

2. Уваров Е.Ф. Электротехнические свойства полупроводниковых соединений $\mathrm{A}_{3} \mathrm{~b}_{5}$, облучаемых быстрыми электронами и нейтронами // Обзоры по электронной технике. Сер. 2. Полупроводниковые приборы. - М.: ЦНИИ Электроники, 1979. - Вып. 9. - 68 с.

3. Пенков С.В., Мокричкий В.А., Перегузов Д.А., Тарцелашвили Г.Т. Физико-технические основы радиационной технологии полупроводников. Одесса: Астропринт. - 2002. - 300 с.

4. Завадський В.A., Зубарєв В.В., Лєнков С.В., Tapicлашвілі $\Gamma . T$. Вплив опромінення швидкими електронами на властивості арссніду галію // Вісн. НАУ. - 2002. - №4. - C. 50-51.

5. Зубарсв В.В., Мокрицький В.A., Салімов Р.М., Савельєв A.B. Радіаційна модифікація параметрів та вивчення стійкості напівпровідникових виробів електронної техніки для космічної апаратури // Нац. акад. оборони України. Тр. Акад. - К.: - 2002. №39. - C. 293-294.

6. Мокрицкий B.A., Завадский B.A. Влияние радиационной обработки на параметры интегральных преобразователей температуры // Технология и конструирование в электронной аппаратуре. -2001 . - № 1. - С. 25-27.

Стаття надійшла до редакції 11.04 .03

\section{С.В. Ленков, Д.В. Лукомский, В.А. Мокрицкий, В.А. Завадский, Р.М. Салимов}

Радиационно-термическая корректировка свойств арсенида галлия

Представлены результаты исследований возможности корректировки параметров и характеристик электронных приборов на основе арсенида галлия, который используется в радиоэлектронных элементах бортовой аппаратуры. Приведены экспериментальные данные относительно управления свойствами подкладок и эпитаксийных шаров арсенида галлия за счет облучения нейтронами и последующего отжига.

S.V. Lenkov, D.V. Lukomski, V.A. Mokrizki, V.A. Zavadski, R.M. Salimov

Radiation-thermal adjustment of properties of gallum arsenide

The outcomes of researches of a possibility of adjustment of parameters and characteristics of electronic devices on a bottom to gallium arsenide are presented which is used in radio electronic elements of an onboard equipment. The experimental data, concerning management of properties of undercoats of spheres of gallium arsenide are indicated at the expense of an exposure by neutrons and subsequent annealing. 